University of California, Santa Barbara, Main Library

Expanded

Continuing Education-III

Copyright-More Views

Oregon ACRL Chapter Meets ....163

News from the Field

People

Publications

Classified Advertising

\section{COLLEGE \\ E RESEARCH \\ LIBRARIES \\ MEUlS}

NO, 6 - JUNE 1978

\title{
University of California, Santa Barbara, Main Library Is Expanded and Functionally Reintegrated
}

A newly completed four-story addition to the existing main library at the University of California, Santa Barbara, was opened to the public during the first week of November 1977. The addition consists of approximately 91,000 net square feet; another 6,700 were added to the existing main library as part of alterations designed to provide architectural and functional integration of the central complex, which after construction totals 236,762 net square feet, with an outside gross square footage of 344,417 .

For many functional units the final move was the last of a long series of interim moves which during a period of two years were necessary to allow alterations to be made. The interim move sequence had been designed to obtain the least movement of functions, staff, equipment, and books possible during the period of construction while maintaining as nearly as possible normal services to the public and access to materials. Nevertheless, it was a difficult time for all. During the two-year construction, some 200,000 volumes were removed to outside locations; but throughout the period, at least $1,000,000$ volumes were retained in the building along with the 350,000 -volume government publications collection, the 400,000 -sheet map and aerial photograph collection, and all other nonvolume materials.

The decision had been made prior to commencement of construction that, insofar as possible, materials would be retained in the essentially open stack library and that seating would be displaced as necessary to perform the alterations construction. The main unit had opened in 1967 with approximately 3,000 reader stations, and this number gradually diminished to 400 by October 1977 due to displacement by shelving for new books and other materials. During the construction years, additional outside seating was made available in classrooms in other buildings. Upon completion of the move into the completed complex, 3,266 reader stations will have been pro vided. The designed volume capacity of the com plex is $1,508,430$ volumes

The net square footage of the complex equals approximately seven acres, arranged as follows: floors 1 and 2 consist of approximately 75,000 net square feet each; floors 3 and 4 consist of about 38,000 each; and 5 through 8 , approximately 11,600 each.

The design concept was to provide those facilities on the first several floors that would filter out users not primarily interested in research and/or study of library materials. Surveys had indicated that most persons come to the library to read materials carried in by themselves, and to read "ephemeral materials." With this in view, the following functions were placed on the first floor: the general current periodical reading area and serials service desk; new book display; classrooms; a great many study stations; the main lending desk; reserve book service; government publications; map and imagery collection; newspapers; education curriculum laboratory; public typewriters; and, outside of exit controls, a latestudy area in close proximity to an outside porch housing food vending machines. 
Fact Sheet on UCSB Library Building

Project Cost
Gross Area
Net Area
Nonassignable Area
Percent Efficiency
Square-Foot Cost
Building Cost
Equipment Cost
Book Capacity
Seating Capacity

Project Cost

New Area

$\$ 8,271,000$

122,500

91,000

31,500

74

$\$ 51.46$ gross

$\$ 6,446,000$

$\$ 444,000$

535,176

1,387
Renovated Area

$\$ 2,225,000$

209,610

146,902

62,708

70

$\$ 10.61$ gross

$\$ 1,742,000$

$\$ 33,000$

973,254

1.879
Total

$\$ 10,496,000$

332,110

237,902

94,208

$\$ 8,188,000$

$\$ 477,000$

$1,508,4,30$

3,266
The heart of the second floor consists of the centrally located interdisciplinary service center radiating about the main card catalog. North of the catalogs, occupying about 40,000 square feet, is the Sciences-Engineering Library with its current periodical reading area and reader services desk; a full-service and self-service copy center at which are ganged a number of coin-operated machines; and a room for terminals for use with computerized information systems. East of the catalogs is the interlibrary loan service, and to the west is the microform reading and service area. To the south is the general reference service desk; the locational-information desk, and a very large $(15,000$ net square feet) "oldfashioned" roomful of general reference materials such as bibliographies and periodical indexes. A little further to the south is a room of 2,700 square feet that houses both the Black Studies and the Chicano Studies library units sharing a combined service operation. The concept of the second floor is that a serious researcher will have available all of the bihliographical and reader services as well as the multi- and interdisciplinary services of specialist librarians, copying facilities, computer terminal facilities, and interlibrary loan services as well as micromaterial to be able to complete bibliographies before going to the stacks.

Since the processing staff requires ready access to the second floor materials as well as the public, the catalog department, with its in-process materials, the bibliographic searching department, and the order department, were located on the third floor. Also on the third floor are the university librarian's offices and the special collections closed-stack and service/reading area.

On floors 4 through 8 are located the major part of the library's general collections, exclusive of sciences, music, and art. The Oriental collections are located together, with services to them on the fifth floor

Colloquium rooms that serve either for seminars involving library materials or as group studies are scattered throughout the facility as are approximately 100 faculty studies.
Vertical transportation is by stairs as well as three elevators servicing the eight-story tower, one elevator serving the two-story north wing, and two elevators servicing the four-story addition.

Prior to this most recent construction the main library consisted of a single building totaling about 140,000 net square feet with only two entrances. It had been constructed in three units: the first completed in 1954 consisting of 28.000 square feet, the second completed in 1961 with 38,000 square feet, and the third unit completed in 1967 with about 73,000 squatre feet. The earlier unit had been very serviceable but had become quite crowded and architecturally disfunctional due to the many vestiges of the past that had accumulated in the forms of walls and passageways that eventually seemed to exist without logic or usefulness.

The completed unit still has only two public entrances and the library, for the most part, has open stacks. The four-story addition features a vaulted ceiling with sky light on the fourth floor,

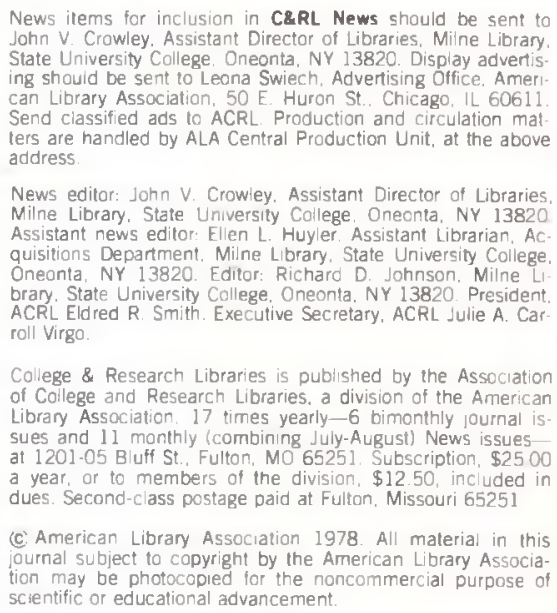

College \& Research Libraries is published by the Association of College and Research Libraries, a division of the American Library Association, 17 times yearly -6 bimonthly journal is. sues and 11 monthly (combining July-August) News issues at 1201-05 Bluff St., Fulton, MO 65251. Subscription, $\$ 2500$ a year, or to members of the division. \$12.50, included in dues. Second-class postage paid at Fulton. Missouri 65251

(c) American Library Association 1978. All material in this journal subject to copyright by the American Library Association may be photocopied for the noncommercial purpose of scientific or educational advancement. 


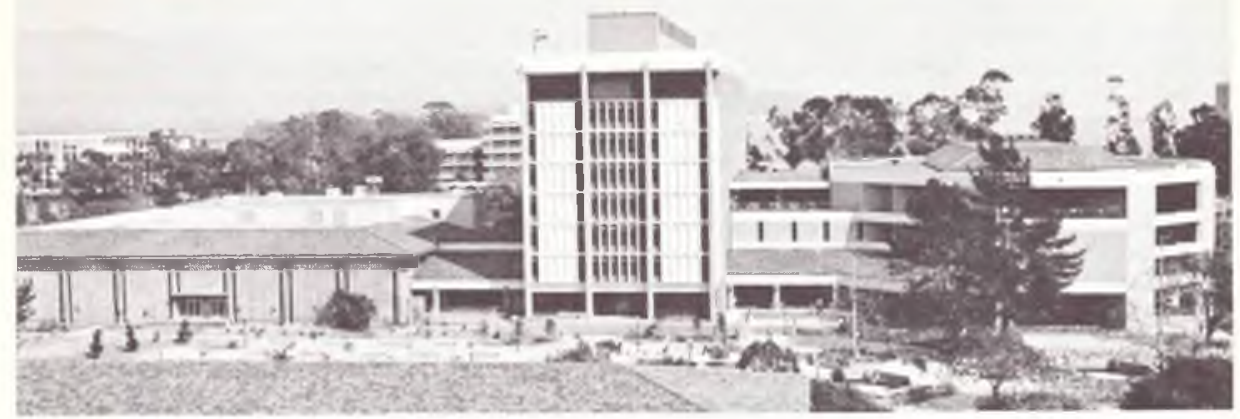

Right, recent four-story addition; center, 1967 eight-story addition; left, original two-story units.

West lobby and staircase showing exposed duct work and concrete waffle ceiling.

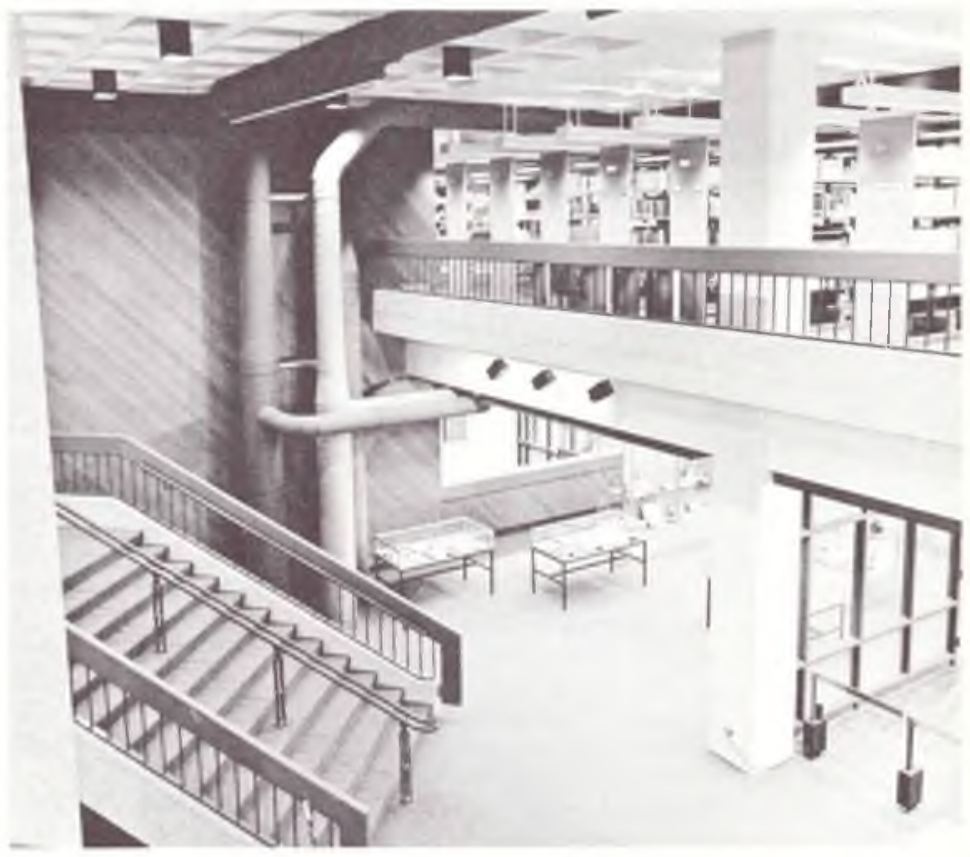

outside reading decks on all floors except the first, a functionally integrated interior, carpeting throughout, and a split-level treatment of the first floor.

Various interior finishes and furnishings reflect the decades during which they were created. Because of fire regulations, the light oak of the 1950 s has been replaced by sheet steel, sheet rock, or plaster construction. Some areas still exhibit the walnut paneling that was fashionable in the sixties, and the newest addition exhibits the aesthetics of open duct-work ceilings.

Furnishings also range from light oak of the fifties and the steel and high-pressure laminates of the sixties through the redwoods and brightaccent fabrics of the seventies.

The entire unit is air conditioned and in conformance with the most current seismic codes (I wonder why the Titanic pops into mind) as well as conforming to the federal and state requirements for facilities for the handicapped.

Architects were Arendt, Mosher, and Grant of Santa Barbara. The general contractor for the addition project was Viola Inc., Oxnard, California; and for the alteration project, J. W. Bailey Construction Co., Santa Barbara.-Eugene E. Graziano, Assistant University Librarian, Services. 